\title{
Lessons Learned From Efforts To Restore Oyster Populations In Maryland And Virginia, 1990 To 2007
}

\author{
VS Kennedy \\ DL Breitburg \\ MC Christman \\ Mark Luckenbach \\ Virginia Institute of Marine Science \\ Kennedy Paynter
}

See next page for additional authors

Follow this and additional works at: https://scholarworks.wm.edu/vimsarticles

Part of the Marine Biology Commons

\section{Recommended Citation}

Kennedy, VS; Breitburg, DL; Christman, MC; Luckenbach, Mark; Paynter, Kennedy; Kramer, J; Sellner, Kevin; Dew-Baxter, J; Keller, C; and Mann, Roger L., Lessons Learned From Efforts To Restore Oyster Populations In Maryland And Virginia, 1990 To 2007 (2011). Journal Of Shellfish Research, 30(3), 719-731. $10.2983 / 035.030 .0312$

This Article is brought to you for free and open access by the Virginia Institute of Marine Science at W\&M ScholarWorks. It has been accepted for inclusion in VIMS Articles by an authorized administrator of W\&M ScholarWorks. For more information, please contact scholarworks@wm.edu. 


\section{Authors}

VS Kennedy, DL Breitburg, MC Christman, Mark Luckenbach, Kennedy Paynter, J Kramer, Kevin Sellner, J Dew-Baxter, C Keller, and Roger L. Mann 


\title{
LESSONS LEARNED FROM EFFORTS TO RESTORE OYSTER POPULATIONS IN MARYLAND AND VIRGINIA, 1990 TO 2007
}

\author{
VICTOR S. KENNEDY, ${ }^{1 *}$ DENISE L. BREITBURG, ${ }^{2}$ MARY C. CHRISTMAN, ${ }^{3}$ \\ MARK W. LUCKENBACH, ${ }^{4}$ KENNEDY PAYNTER, ${ }^{5}$ JONATHAN KRAMER, ${ }^{6}$ \\ KEVIN G. SELLNER, ${ }^{7}$ JODI DEW-BAXTER, ${ }^{8}$ CHERIE KELLER ${ }^{9}$ AND ROGER MANN ${ }^{10}$ \\ ${ }^{1}$ Horn Point Laboratory, University of Maryland Center for Environmental Science, Box 775, Cambridge \\ MD 21613; ${ }^{2}$ Smithsonian Environmental Research Center, Edgewater, MD 21037; ${ }^{3}$ MCC Statistical \\ Consulting LLC, Gainesville, FL 32605; ${ }^{4}$ Eastern Shore Laboratory, Virginia Institute of Marine Science, \\ Wachapreague, VA 23480; ${ }^{5}$ Chesapeake Biological Laboratory, University of Maryland Center for \\ Environmental Science, Box 38, Solomons, MD 20688, and Department of Biology, University of \\ Maryland, College Park, MD 20742; ${ }^{6}$ Maryland Sea Grant, University System of Maryland, College \\ Park, MD 20740; ${ }^{7}$ Chesapeake Research Consortium, Inc., Edgewater, MD 21037; ${ }^{8}$ Versar Inc. ESM, \\ Columbia, MD 21045; ${ }^{9}$ University of Florida, Department of Biology, Gainesville, FL 32611; ${ }^{10}$ Virginia \\ Institute of Marine Science, Gloucester Point, VA 23062
}

\begin{abstract}
A century-long decline of the fishery for the Eastern oyster Crassostrea virginica (Gmelin, 1791) in Maryland and Virginia stimulated numerous efforts by federal, state, and nongovernmental agencies to restore oyster populations, with limited success. To learn from recent efforts, we analyzed records of restoration and monitoring activities undertaken between 1990 and 2007 by 12 such agencies. Of the 1,037 oyster bars (reefs, beds, or grounds) for which we obtained data, $43 \%$ experienced both restoration and monitoring, with the remaining experiencing either restoration or monitoring only. Restoration activities involved adding substrate (shell), transplanting hatchery or wild seed (juvenile oysters), bar cleaning, and bagless dredging. Of these, substrate addition and transplanting seed were common actions, with bar cleaning and bagless dredging relatively uncommon. Limited monitoring efforts, a lack of replicated postrestoration sampling, and the effects of harvest on some restored bars hinders evaluations of the effectiveness of restoration activities. Future restoration activities should have clearly articulated objectives and be coordinated among agencies and across bars, which should also be off limits to fishing. To evaluate restoration efforts, experimental designs should include replication, quantitative sampling, and robust sample sizes, supplemented by pre- and postrestoration monitoring.
\end{abstract}

KEY WORDS: Chesapeake Bay, management, Maryland, monitoring, oyster fishery restoration, Virginia, Crassostrea virginica

\section{INTRODUCTION}

During the late 19th century, the Eastern oyster Crassostrea virginica (Gmelin, 1791) fishery in Maryland and Virginia was the largest in the world. The combined landings in both states represented about $59 \%$ of all U.S. landings in the early 1890 s and more than 3 times the combined harvest of all foreign countries at that time (Stevenson 1894). At their peaks, landings for the 3 states were estimated to be 19.5 million standard U.S. bushels in Maryland in 1884 and 10.6 million standard U.S. bushels in Virginia in 1904 (Fig. 1). Most of the landings were from Chesapeake Bay, but a small quantity was from the coastal bays on the Atlantic coast of both states.

During the next century, yields declined (Fig. 1) because of overfishing, habitat destruction, and disease (Kennedy \& Breisch 1983, Kennedy 1989, Rothschild et al. 1994, Hargis \& Haven 1999). During this period of decline, resource agencies in Maryland and Virginia, as well as a number of federal and nongovernmental organizations, attempted numerous restoration efforts, with limited success (Brooks 1891, Kennedy \& Breisch 1983, Kennedy 1989). Initial restoration efforts apparently were implemented solely to maintain the fishery. However, during the past two decades it has become apparent that oysters provide important ecological services (Newell 1988, Kennedy 1996).

*Corresponding author. E-mail: kennedy@umces.edu DOI: $10.2983 / 035.030 .0312$
Widespread recognition of the ecological importance of oysters was sparked by Newell's (1988) paper that proposed that Chesapeake Bay had changed from a benthic-based ecosystem to a more pelagic ecosystem, and attributed that change to the long-term depletion of more than $99 \%$ of the standing stock of oysters. Subsequent studies added to our understanding of the role of oyster bars (reefs, beds, or grounds) as habitat for other estuarine organisms, including commercial species like striped bass Morone saxatilis (Walbaum, 1792) and the blue crab Callinectes sapidus Rathbun, 1896 (e.g., Coen et al. 1999, Breitburg et al. 2000, Coen \& Luckenbach 2000). These insights into the ecological functions of oyster bars encouraged additional restoration activities (e.g., Rodney \& Paynter 2006, Grabowski \& Peterson 2007).

Despite the large investment in efforts to restore oyster populations and the oyster fishery in Maryland and Virginia during the past two decades, there has been no comprehensive analysis of what was done or the outcome of restoration attempts. To evaluate success or failure of these efforts, we developed a database of restoration and monitoring activities from 1990 to 2007 in Chesapeake Bay and the coastal bays. The intent was to provide a synthesis of the lessons learned with regard to the specific scientific and management goals (resource exploitation, ecological function, or both) that have driven these restoration efforts and, in particular, any successes in reaching such goals. We also hoped that the synthesis could be used to develop a model for future data archiving efforts as well as future 


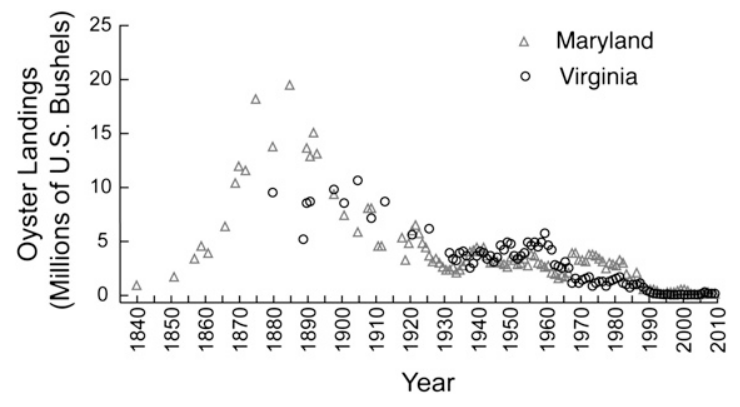

Figure 1. Landings of Eastern oysters from 1840 to the present in Maryland and Virginia. Data derived from Grave (1912), Hargis and Haven (1988), and unpublished data provided by E. Campbell of Maryland's Department of Natural Resources and J. Wesson of Virginia Marine Resources Commission.

restoration actions incorporating only those practices most effective in rehabilitating depleted populations.

The task of evaluating the success or failure of restoration activities proved to be challenging given: (1) the dispersed nature of the data, (2) difficulty accessing the data, and (3) widely varying formats or statistics used by data providers in some cases. Unfortunately, specific restoration goals, whether qualitative or quantitative, were not identified for many restoration efforts. In some instances, it is possible to infer the goals, but they are less certain in others. The lack of clear measures makes evaluating success toward meeting inferred goals difficult. Nevertheless, we developed some key observations, coupled with cautionary comments about data limitations. With these limitations in mind, we feel the database has significant value and provides a number of avenues to interested researchers for more detailed analyses. We also feel that lessons learned from efforts that produced data of sufficient detail in one state should be broadly applicable Bay-wide and beyond, and should inform future efforts as new restoration and monitoring protocols are implemented.

This article summarizes the results of our efforts in assembling this extensive database as well as an accounting of the restoration and monitoring activities. It also provides an initial metadata analysis structured by a series of questions used to frame the study (Table 1). As this summary demonstrates, although some of these questions could be answered by the data we collected, a number of others remain unanswered as a result of a paucity of information or poor experimental design with respect to testing effective strategies. This is not to say that the restoration efforts were not successful. Rather, data for determining success were often not collected or were not made available to us.

\section{DATABASE DEVELOPMENT AND ARCHITECTURE}

To develop the database, we requested data from agencies involved in restoration in Maryland and Virginia and worked to develop an architecture for the database that would accommodate different inputs and allow for analysis. We assembled, collated, and analyzed 73,549 records of oyster restoration and monitoring activities between 1990 and 2007 (ORET 2009). Additional data from an experimental restoration program in the Great Wicomico River estuary (Schulte et al. 2009) were not included in the core database but are described in the discussion.

We received data from 12 sources in Maryland and Virginia (Table 2) and constructed a database using Microsoft Access.
The data were assembled in five linked tables that incorporated site information, monthly data in relation to a particular Bay geographical segment (there are 92 segments in the Bay; see USEPA (2008)), information on water quality in each segment, a listing of restoration activities, and a listing of monitoring activities (see ORET (2009) for a view of the database architecture and how the user interface operates). The resulting 73,549 entries cover the diverse set of activities that comprised restoration and monitoring of oyster bars (a distinct geographical unit that corresponds to a historical oyster reef, bed, or ground) in the Bay. Entries are both geographically and temporally referenced, and the database is accessible for statistical (e.g., SAS, R) and GIS (e.g., ArcGIS) analyses. It can be found at http://ches.communitymodeling.org/models.php\#ORET.

\section{Restoration}

Five major types of restoration activities were defined in the database (Table 3). These fell into two categories: (1) efforts to enhance the adult stock of oysters on a bar to provide for sustained reproduction or for commercial harvests and (2) efforts to improve the physical habitat of a bar to encourage subsequent larval settlement or to remove diseased oysters.

\section{Monitoring}

Various types of monitoring are relevant for evaluating restoration success. Monitoring of bars not receiving restoration activities (nonrestored bars) provides important reference points (or controls) for comparison with sites receiving restoration efforts (restored bars). Data collected at nonrestored and restored bars included date of collection, measurements of oyster abundance, individual size, and disease prevalence and intensity.

\section{QUERIES AND METADATA ANALYSES}

In our analyses, we considered the timing of an activity (whether restoration or monitoring) and geographically referenced location of that activity (i.e., a bar) to represent a discrete restoration or monitoring "activity" for analysis. So, if an oyster bar received numerous substrate additions or was monitored numerous times, each addition or monitoring event counted as an individual activity. The metadata analyses that follow summarize information in the context of this operational definition.

We structured the initial queries of the database to develop and understand the inventory of effort associated with oyster restoration activities throughout the $18 \mathrm{y}$ in the database. Such basic queries are informative in terms of understanding the scale and pattern of oyster restoration. However, there are important caveats to acknowledge at the outset. These are as follows:

- Although we made exhaustive efforts to gather all relevant information from the study period, the data set does not capture all restoration and monitoring activities during this time, either because the data were never recorded and archived or because data were not made available to us. We received complete data sets from the Maryland Department of Natural Resources, University of Maryland, Oyster Recovery Partnership, Potomac River Fisheries Commission, U.S. Army Corps of Engineers Baltimore District, and the Academy of Natural Sciences/Morgan State University. Unfortunately, data sets from the Virginia Institute of Marine Science, Virginia Marine Resources Commission, and the 
TABLE 1.

Questions asked of the assembled data on oyster restoration efforts in Chesapeake Bay, 1990 to 2007.

\begin{tabular}{|c|c|c|}
\hline Category & Questions asked of the data & Were answers available? \\
\hline Oyster restoration inventory & $\begin{array}{l}\text { What efforts were made-where, when, by whom? } \\
\text { How was restoration attempted (substrate } \\
\text { addition, seed transplanting, and so forth)? }\end{array}$ & Data were available for most efforts. \\
\hline Rationale for restoration efforts & $\begin{array}{l}\text { Why was restoration attempted? For ecological } \\
\text { or fishery reasons, or both? } \\
\text { What proportion of efforts focused on enhancing } \\
\text { habitat, broodstock, or disease tolerance? }\end{array}$ & Rationale was not always evident. \\
\hline Monitoring of restoration efforts & $\begin{array}{l}\text { Was any follow-up monitoring performed? } \\
\text { If so, what data were collected and when, how } \\
\text { often, for how long, and by whom? }\end{array}$ & Data were not always available. \\
\hline $\begin{array}{l}\text { Availability and utility of } \\
\text { monitoring data }\end{array}$ & $\begin{array}{l}\text { Were monitoring data analyzed or are they } \\
\text { available for analysis? } \\
\text { If analyzed, what was learned about the success } \\
\text { of the restoration activity? }\end{array}$ & $\begin{array}{l}\text { We analyzed the available data, but } \\
\text { the success of many restoration } \\
\text { activities remains unclear. }\end{array}$ \\
\hline Restoration success or failure & $\begin{array}{l}\text { What constitutes success or failure of a } \\
\text { restoration effort, and what performance } \\
\text { measures are involved in this decision? } \\
\text { Why did some restoration efforts succeed and } \\
\text { others fail? }\end{array}$ & $\begin{array}{l}\text { We were not able to answer these } \\
\text { questions with the available } \\
\text { data. }\end{array}$ \\
\hline Scale of restoration efforts & $\begin{array}{l}\text { To what extent was the scale of a restoration a } \\
\text { factor in its success or failure? } \\
\text { Can we determine the appropriate scale for use } \\
\text { in a restoration effort? } \\
\text { What production level (spat per year) is needed } \\
\text { for a successful restoration? }\end{array}$ & $\begin{array}{l}\text { We were not able to answer these } \\
\text { questions. }\end{array}$ \\
\hline Long-term trends & $\begin{array}{l}\text { Are there differences in the length of time needed } \\
\text { for successful restoration in different regions of } \\
\text { Chesapeake Bay? } \\
\text { Do sanctuaries work and under what conditions? }\end{array}$ & $\begin{array}{l}\text { We were not able to answer these } \\
\text { questions. }\end{array}$ \\
\hline Ecosystem factors & $\begin{array}{l}\text { Are data on water quality, harmful algal blooms, } \\
\text { disease, or other relevant variables available for } \\
\text { sites that were not monitored after receiving a } \\
\text { restoration activity? }\end{array}$ & Data are not always available. \\
\hline Oyster disease links & $\begin{array}{l}\text { Are oysters evolving tolerance to disease in } \\
\text { Chesapeake Bay? } \\
\text { How successful have efforts to use selectively bred, } \\
\text { disease-tolerant strains been in restoration? }\end{array}$ & $\begin{array}{l}\text { We were not able to answer these } \\
\text { questions. }\end{array}$ \\
\hline Socioeconomic factors involved & $\begin{array}{l}\text { What socioeconomic factors (cultural, historical, } \\
\text { political) have influenced restoration efforts? }\end{array}$ & $\begin{array}{l}\text { We were not able to answer this } \\
\text { question. }\end{array}$ \\
\hline Economics of restoration & $\begin{array}{l}\text { How much have restoration activities cost during the } \\
\text { study period, and what has been the economic } \\
\text { effect on the fishery? }\end{array}$ & $\begin{array}{l}\text { We were not able to answer these } \\
\text { questions. }\end{array}$ \\
\hline
\end{tabular}

Chesapeake Bay Foundation were incomplete or summarized at scales other than that needed for statistical analysis (e.g., as bar summaries rather than raw data), or were not in electronic form. Furthermore, information on bar status with respect to harvest closures in Virginia was not available at the time of our analysis.

- In terms of monitoring efforts, many data were collected for purposes not related directly to restoration. We collated these data in an attempt to assess restoration success, but with the caveat that they are not always temporally or spatially associated with restoration activities.
- Legal harvesting on bars included in the database has varied temporally and spatially, which confounds our ability to determine whether changes on a bar are related to restoration, disease, or harvesting. For example, monitoring for disease in Maryland (http://dnr.maryland.gov/fisheries/commercial/ oysters/fallsurvey/FSintro.html) was often conducted at a number of sentinel bars that also were open to legal harvest throughout the period analyzed. Specific data pertaining to the harvest status of given bars in Maryland have been added to the database when possible. However, there is no direct correspondence between harvest regulations and actual harvest 
TABLE 2.

Sources of data on oyster restoration and monitoring activities in Maryland and Virginia waters (Chesapeake Bay and coastal systems) from 1990 to 2007.

\begin{tabular}{cl}
\hline \hline Type of agency & \multicolumn{1}{c}{ Name of agency } \\
\hline State management & Maryland Department of Natural Resources \\
& Potomac River Fisheries Commission \\
& Virginia Marine Resources Commission \\
Research and & Academy of Natural Sciences/Morgan State \\
educational & University Estuarine Research Center \\
& University of Maryland \\
& University of Maryland Center for \\
& Environmental Science \\
Virginia Institute of Marine Science \\
Federal & U.S. Army Corps of Engineers \\
Oyster Recovery Partnership \\
Chesapeake Bay Foundation, Maryland and \\
Virginia branches \\
Living Classrooms Foundation \\
South River Federation
\end{tabular}

at bars included in the database because bars open to harvest may or may not have been harvested in any given year.

- Last, few data exist to quantify the extent of illegal harvest (poaching) on restored bars and its effect on restoration success. For example, although Paynter et al. (2010) reported that 10 of 27 bars in their study had been affected by illegal harvest, these numbers may or may not be representative of the extent of poaching Bay-wide.

Within these constraints, we focused on two sets of questions in this metadata analysis, with each question addressed as a separate section in the following pages:

- What restoration efforts have been made? How, where, when, and by whom?
- What monitoring efforts have been made? How, where, when, by whom, and how did this monitoring intersect with restoration efforts?

Note that although we use the adjective "restored" for bars receiving a restoration activity, it does not mean that the activity was successful in enhancing adult stock or habitat. Note also that the number of bars listed in various tables may not agree from table to table. This occurs because multiple organizations could perform restoration activities, monitoring, or both on the same oyster bar. Thus, if a state agency, a university, and a private organization performed activities on the same bar, the bar might show up 3 times in the data in a particular table, but may represent just 1 bar in another table.

\section{RESULTS}

The compiled data revealed a distribution of 1,037 bars Baywide and in the coastal bays (Fig. 2) that were targeted for restoration activity or monitoring between 1990 and 2007. During the study period, restoration activities took place at 378 bars in Maryland and 216 bars in Virginia, and monitoring occurred at 453 and 437 bars in Maryland and Virginia, respectively. The sum of these numbers $(1,484)$ is greater than the value of 1,037 bars targeted for restoration or monitoring, indicating that some bars were both restored and monitored. Of the 1,037 bars for which we obtained data, $43 \%$ experienced both restoration and monitoring, with the remaining experiencing either restoration or monitoring alone.

Because a given bar might be restored or monitored (or both) several times between 1990 and 2007, this practice yielded more restoration and monitoring data points than a simple sum of the bars that were manipulated. This is why the number of restoration and monitoring activities undertaken in the two states (total, 11,936; Table 4) is much higher than the number of bars restored, or monitored, or both. Restoration alone approximated $18 \%$ of all activities in both states whereas monitoring with or without restoration comprised about $82 \%$ of the activities (Table 4 ).

TABLE 3.

Types of activities used to restore oyster populations in Maryland and Virginia from 1990 to 2007.

\begin{tabular}{|c|c|}
\hline Activity & Description \\
\hline \multicolumn{2}{|l|}{ Adult stock enhancement } \\
\hline Wild seed transplanting & $\begin{array}{l}\text { Wild seed (young oysters, or spat) are harvested and relocated to areas with low natural recruitment of spat, } \\
\text { but where spat are expected to grow to commercial and reproductive size. }\end{array}$ \\
\hline Hatchery seed planting & $\begin{array}{l}\text { Oyster hatcheries produce larvae that are then allowed to settle on shell as spat for subsequent placement in } \\
\text { areas with low natural recruitment, but where spat are expected to grow to commercial and reproductive } \\
\text { size. }\end{array}$ \\
\hline \multicolumn{2}{|l|}{ Habitat enhancement } \\
\hline Substrate addition & $\begin{array}{l}\text { Large-scale plantings of oyster shell (and occasionally other substrate) in areas expected to receive consistent } \\
\text { settlement of larvae on the substrate. These spat may then grow in the area or may subsequently be } \\
\text { transplanted elsewhere as seed. Substrate may also be used to build up a base on which seed can be laid. }\end{array}$ \\
\hline Bar cleaning & $\begin{array}{l}\text { An activity to maximize survivorship of oysters by removing infected animals from a bar. Commercial } \\
\text { fishers are hired to use escalator dredges to remove all live oysters, returning empty shell to the bar. The } \\
\text { process excavates the bottom to a depth of } \sim 0.3 \mathrm{~m} \text { and, through agitation and turnover, sediment is } \\
\text { washed off the shell before the shell is returned to the bar. }\end{array}$ \\
\hline Bagless dredging & $\begin{array}{l}\text { An activity that drags an oyster dredge with no (or an open) catch bag across a bar, stirring up oysters, } \\
\text { shell, and sediment. The oysters and shell resettle while sediment is dispersed into the water column } \\
\text { and, under appropriate conditions of currents, washed away from the bar. Bagless dredging is thought } \\
\text { to be less disruptive of the structural integrity of the bar than bar cleaning with power dredges. }\end{array}$ \\
\hline
\end{tabular}




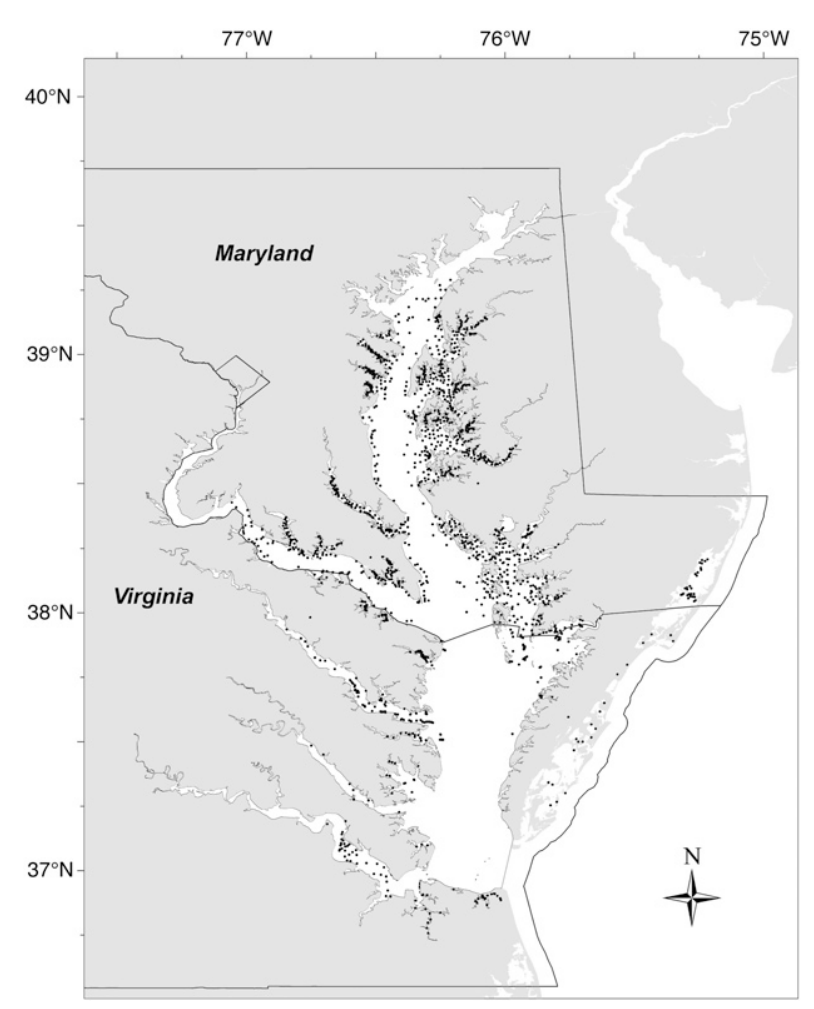

Figure 2. Spatial coverage of Eastern oyster bars with restoration or monitoring activities in Chesapeake Bay and coastal sites in Maryland and Virginia from 1990 to 2007.

The effort in Maryland reflected in our database surpassed that in Virginia in both restoration and monitoring (Table 4). This results, in part, from the fact that, although Virginia has a long history of restoration activities on public oyster bars dating back to at least 1915 (Wesson et al. 1999), georeferenced data suitable for inclusion in our database were available only from 1999 onward.

\section{What Restoration Efforts Have Been Made?}

Of the five types of restoration activities used by various agencies, the traditional practice of adding substrate, usually oyster shell and ostensibly to augment natural recruitment, involved more bars (240 in Maryland and 177 in Virginia) than any other activity (Table 5). However, in terms of restoration activities, it was second to transplanting seed (Table 4). The remaining restoration techniques - bar cleaning and bagless dredging - were rarely used (Tables 4 and 5).

There were habitat differences in terms of restoration in the Bay (main stem and tributaries) and the coastal bays (Table 5), a reflection of the fact that most oyster bars occur in tributaries rather than in the main stem or the coastal bays. (There are 1,327 bars in the Bay's tributaries, 237 bars in the Bay's main stem, and 121 bars in the coastal bays.) Substrate was added to 317 bars in the Bay's tributaries, 47 bars in the main stem, and 45 bars in the coastal seaside bays. Tributaries also received most of the seed transplants. Bar cleaning was undertaken almost exclusively on tributary bars, with Maryland conducting bar cleaning at more bars than Virginia. Only one seaside bar was cleaned (in Maryland). Bagless dredging was used only in Virginia, at 11 bars in the tributaries and four in the main stem.
The pattern of restoration changed during the course of the study period (Fig. 3). In Maryland, substrate addition increased through the 1990s, peaking at 45 bars in 1999, followed by lower and relatively constant usage at about 30 bars through 2005 , and declining thereafter to 5 bars in 2007 as substrate became scarce. The number of bars receiving wild seed transplants was high in 1992 (52) and 1998 (58), and declined thereafter as use of hatchery seed began to dominate. Transplanting hatchery seed increased from 1997 onward, reaching its highest level in 2006 (48), when it exceeded wild seed transplants (4) by about 10fold. Bar cleaning began in 2003 (6 bars) in Maryland, with a modest increase to 14 bars in 2007.

As noted earlier, our information on restoration activities in Virginia covers a shorter period than in Maryland (Fig. 3). In our database, substrate addition began in 1999, with 37-47 Virginia bars receiving substrate during the next $4 \mathrm{y}$. No substrate addition was reported in 2003; however, 40 bars were supplemented with substrate the following year, declining by nearly half by 2006. Wild seed transplanting began, according to our database, in 1996 at 1 Virginia bar, with the highest number (23 bars) receiving wild seed in 2000. As in Maryland, use of wild seed was eventually surpassed by the use of hatchery seed, beginning in 2001 to 2002, with hatchery seed placed on 15 bars. Bar cleaning was conducted at 8 and 5 bars in 2000 and 2001 , respectively, and bagless dredging was only conducted in 1999, at 15 bars. A variety of additional activities (including seed movement and construction of new bars; see, for example, Schulte et al. (2009)) have also been conducted in Virginia over many years, chiefly in support of the oyster fishery. We did not consider this set of efforts, however, because sufficient data were not available for analysis.

Multiple organizations have been involved in oyster restoration in the region (Tables 4 and 6). Most efforts, however, were conducted by the two state agencies with mandated restoration responsibilities: Maryland's Department of Natural Resources (DNR) and Virginia's Marine Resources Commission (VMRC). The DNR performed 6,068 of 7,914 activities in Maryland whereas VMRC performed 2,115 of 4,022 activities in Virginia (Table 4).

With respect to the number of oyster bars that were restored in Maryland (Table 6) as well as the number of restoration activities (Table 4), the DNR focused on substrate addition and wild seed transplanting, with hatchery seed transplants being uncommon. The Oyster Recovery Partnership predominantly used hatchery seed transplants and bar cleaning (the Partnership was the only Maryland agency to perform this latter activity). The Chesapeake Bay Foundation restored nearly equal numbers of bars with hatchery seed and substrate (Table 6), but used hatchery seed more often (Table 4). No Maryland agency or organization performed bagless dredging during the study period.

In Virginia, VMRC's primary restoration activity was substrate addition, with wild seed transplanted less commonly, hatchery seed not at all, and with bagless dredging and bar cleaning performed at a limited number of locations (Tables 4 and 6). In smaller efforts, the Chesapeake Bay Foundation planted mostly hatchery seed and little wild seed whereas the U.S. Army Corps of Engineers added substrate more often than hatchery seed.

Although some bars were the focus of a single restoration activity, the high number of restoration activities reported for 
TABLE 4.

Number of restoration and monitoring activities by agency in Maryland and Virginia, 1990 to 2007.

\begin{tabular}{|c|c|c|c|c|c|c|c|c|c|c|c|}
\hline \multirow[b]{2}{*}{ State } & \multirow[b]{2}{*}{ Agency } & \multicolumn{6}{|c|}{ Restoration activities } & \multicolumn{3}{|c|}{ Monitoring activities } & \multirow[b]{2}{*}{$\begin{array}{c}\text { All } \\
\text { activities } \\
\text { combined }\end{array}$} \\
\hline & & $\begin{array}{c}\text { Substrate } \\
\text { addition }\end{array}$ & $\begin{array}{l}\text { Hatchery } \\
\text { seed } \\
\text { transplants }\end{array}$ & $\begin{array}{l}\text { Wild seed } \\
\text { transplants }\end{array}$ & $\begin{array}{c}\text { Bar } \\
\text { cleaning }\end{array}$ & $\begin{array}{c}\text { Bagless } \\
\text { dredging }\end{array}$ & $\begin{array}{c}\text { Combined } \\
\text { restoration } \\
\text { activities }\end{array}$ & $\begin{array}{l}\text { Monitoring } \\
\text { with } \\
\text { restoration }\end{array}$ & $\begin{array}{l}\text { Monitoring } \\
\text { without } \\
\text { restoration }\end{array}$ & $\begin{array}{c}\text { Combined } \\
\text { monitoring } \\
\text { activities }\end{array}$ & \\
\hline \multirow[t]{7}{*}{ Maryland } & DNR & 312 & 6 & 444 & 0 & 0 & 762 & 3,595 & 1,711 & 5,306 & 6,068 \\
\hline & $\mathrm{CBF}$ & 114 & 406 & 3 & 0 & 0 & 523 & ND & ND & ND & 523 \\
\hline & ORP & 6 & 178 & 0 & 46 & 0 & 230 & 0 & 0 & 0 & 230 \\
\hline & PRFC & 27 & 1 & 9 & 0 & 0 & 37 & 0 & 0 & 0 & 37 \\
\hline & ANS/MSU & 1 & 3 & 0 & 0 & 0 & 4 & 447 & 114 & 561 & 565 \\
\hline & Others & $8^{*}, 1 \dagger$ & $1 \ddagger$ & 0 & 0 & 0 & 10 & $423 \S$ & $58 \S$ & 481 & 491 \\
\hline & Subtotal & 469 & $595^{\circ}$ & 456 & 46 & 0 & 1,566 & 4,465 & $1,883^{\circ}$ & 6,348 & 7,914 \\
\hline \multirow[t]{5}{*}{ Virginia } & VMRC & 295 & 0 & 56 & 13 & 17 & 381 & 830 & 904 & 1,734 & 2,115 \\
\hline & $\mathrm{CBF}$ & 0 & 130 & 4 & 0 & 0 & 134 & ND & ND & ND & 134 \\
\hline & USACE & 9 & 3 & 0 & 0 & 0 & 12 & 0 & 0 & 0 & 12 \\
\hline & VIMS & 0 & 0 & 0 & 0 & 0 & 0 & 513 & 1,248 & 1,761 & 1,761 \\
\hline & Subtotal & 304 & 133 & 60 & 13 & 17 & 527 & 1,343 & 2,152 & 3,495 & 4,022 \\
\hline Totals & & $773(37) \Phi$ & $728(35) \Phi$ & $516(25) \Phi$ & $59(3) 9$ & $17(<1)$ & 2,093 & $5,808(59)^{* *}$ & $4,035(41)^{* *}$ & 9,843 & 11,936 \\
\hline
\end{tabular}

* U.S. Army Corps of Engineers. $\dagger$ South River Federation. $\ddagger$ Living Classrooms Foundation. §University of Maryland. $\llbracket$ Percent of all restoration activities. ${ }^{* *}$ Percent of all monitoring activities.

Percentages are in parentheses.

ANS/MSU, Academy of Natural Sciences/Morgan State University Estuarine Research Center; CBF, Chesapeake Bay Foundation; DNR, Maryland Department of Natural Resources; ND, no data collected; ORP, Oyster Recovery Partnership; PRFC, Potomac River Fisheries Commission; USACE, U.S. Army Corps of Engineers; VIMS, Virginia Institute of Marine Science; VMRC, Virginia Marine Resources Commission.

both states (Table 4) indicates that restoration efforts during the $18-y$ period occurred multiple times at many of the bars. For example, staff of the DNR conducted substrate additions and wild seed transplants 312 and 444 times, respectively (Table 4), sometimes on the same bars. As another example, substrate addition took place on 35 monitored bars at least two different times, and one monitored bar received substrate addition 10 times during the 1990 to 2007 period (data not shown). In some instances, these multiple activities on a single bar were appar- ently the result of an integrated strategy, such as the addition of substrate followed shortly by the addition of seed. In other instances, however, they appear to be a more haphazard sequence of activities.

We attempted to estimate total acreage restored during the $18-y$ period. Unfortunately, acreage for some activities apparently was never reported. For example, hatchery seed was transplanted 595 times in Maryland, yet data on area covered were available for only $35 \%$ of these activities. In Virginia, only

TABLE 5.

Habitat distribution of oyster bars receiving restoration and monitoring activities by all agencies in the Chesapeake Bay main stem and tributaries, and in the coastal seaside bays, 1990 to 2007.

\begin{tabular}{|c|c|c|c|c|c|c|c|c|c|c|}
\hline \multirow[b]{2}{*}{ State } & \multirow[b]{2}{*}{$\begin{array}{l}\text { Habitat } \\
\text { type }\end{array}$} & \multicolumn{6}{|c|}{ No. of oyster bars receiving restoration activities } & \multicolumn{3}{|c|}{$\begin{array}{c}\text { No. of oyster bars receiving monitoring } \\
\text { activities }\end{array}$} \\
\hline & & $\begin{array}{l}\text { Substrate } \\
\text { addition }\end{array}$ & $\begin{array}{l}\text { Hatchery } \\
\text { seed } \\
\text { transplants }\end{array}$ & $\begin{array}{l}\text { Wild seed } \\
\text { transplants }\end{array}$ & $\begin{array}{c}\text { Bar } \\
\text { cleaning }\end{array}$ & $\begin{array}{l}\text { Bagless } \\
\text { dredging }\end{array}$ & $\begin{array}{c}\text { Combined } \\
\text { restoration } \\
\text { activities }\end{array}$ & $\begin{array}{l}\text { Monitoring } \\
\text { with } \\
\text { restoration }\end{array}$ & $\begin{array}{c}\text { Monitoring } \\
\text { without } \\
\text { restoration }\end{array}$ & $\begin{array}{c}\text { Combined } \\
\text { monitoring } \\
\text { activities }\end{array}$ \\
\hline \multirow[t]{5}{*}{ Maryland } & Main stem & 21 & 10 & 22 & 0 & 0 & 53 & 29 & 28 & 57 \\
\hline & Tributaries & 200 & 107 & 136 & 37 & 0 & 480 & 245 & 137 & 382 \\
\hline & Seaside & 12 & 13 & 2 & 1 & 0 & 28 & 9 & 3 & 12 \\
\hline & Unknown & 7 & 2 & 0 & 0 & 0 & 9 & 0 & 2 & 2 \\
\hline & Total & $240(42)^{*}$ & $132(23)^{*}$ & $160(28)^{*}$ & $38(7)^{*}$ & $0(0)^{*}$ & 570 & $283(62) \dagger$ & $170(38) \dagger$ & 453 \\
\hline \multirow[t]{5}{*}{ Virginia } & Main stem & 26 & 5 & 6 & 0 & 4 & 41 & 33 & 37 & 70 \\
\hline & Tributaries & 117 & 25 & 32 & 13 & 11 & 198 & 105 & 177 & 282 \\
\hline & Seaside & 33 & 0 & 2 & 0 & 0 & 35 & 25 & 58 & 83 \\
\hline & Unknown & 1 & 0 & 0 & 0 & 0 & 1 & 1 & 1 & 2 \\
\hline & Total & $177(64)^{*}$ & $30(11)^{*}$ & $40(15)^{*}$ & $13(5)^{*}$ & $15(5)^{*}$ & 275 & $164(38) \dagger$ & $273(62) \dagger$ & 437 \\
\hline
\end{tabular}

* Percent of all restoration activities in the state. $\uparrow$ Percent of all monitoring activities in the state.

Percentages are in parentheses. 


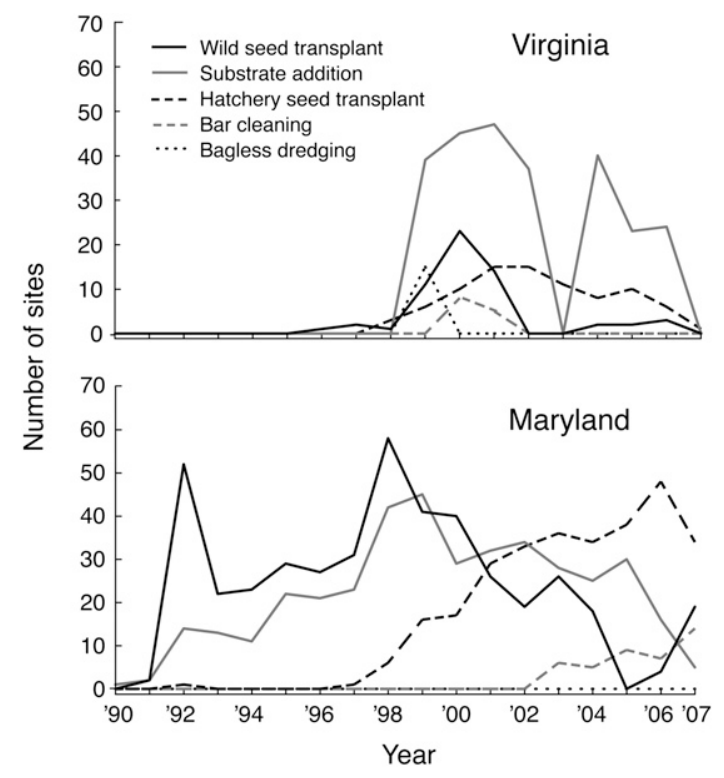

Figure 3. Number of sites receiving a restoration activity in Virginia and Maryland from 1990 to 2007.

$2 \%$ of hatchery seed transplant activities had spatial information available. Acres receiving wild seed were better represented, with $99 \%$ of the additions in Maryland and $68 \%$ in Virginia having associated areal data. In Virginia, reports of acreage restored using substrate addition were fairly complete: $82 \%$ of the reported restoration activities could be related to known acreage. In contrast, Maryland acreage for the activities using substrate addition was known for only $19 \%$ of records. A further hindrance to estimating acreage restored involves the fact that a site may have received a restoration activity or activities repeated times, so an estimate of restored acreage would be inflated. Thus, we cannot provide reasonable estimates of total acreage restored based on data in hand.

\section{What Monitoring Efforts Have Been Made?}

As with restoration, multiple organizations have participated in monitoring (Tables 4 and 6), often with several visits to a bar in a year. The extent of monitoring of oyster bars and restoration bars has been similar in both states throughout the study interval, occurring at 453 bars in Maryland and 437 in Virginia, with tributaries the focus of most efforts in both states (Table 5). In both states, the actual location of monitoring did not always coincide with the location of restoration efforts in oyster bars.

In Maryland, monitoring of restored bars occurred 4,465 times compared with 1,883 times at nonrestored bars (Table 4). Unfortunately, much of the monitoring on restored bars generated only qualitative or semiquantitative data. This problem and the temporal and spatial mismatches between some restoration and subsequent monitoring activities (discussed later) hindered interpretation. In Maryland (Tables 4 and 6), the DNR was the most active agency, monitoring restored bars 3,595 times and nonrestored bars 1,711 times. The Morgan State University Estuarine Research Center (formerly the Academy of Natural Sciences Estuarine Research Center) focused on bars in the Patuxent River and off Calvert Cliffs in the Bay itself, with 561 monitoring activities, predominantly on restored bars. The University of Maryland monitored bars 481 times, also focusing on restored bars.

In contrast to Maryland, more monitoring in Virginia was undertaken at nonrestored bars than at restored bars (Tables 4 and 6). VMRC was the primary monitoring organization, reporting nearly similar monitoring frequencies and number of

TABLE 6.

Number of oyster bars treated by agency between 1990 and 2007.

\begin{tabular}{|c|c|c|c|c|c|c|c|c|}
\hline \multirow[b]{2}{*}{ State } & \multirow[b]{2}{*}{ Agency } & \multicolumn{5}{|c|}{ No. of oyster bars receiving restoration activities } & \multicolumn{2}{|c|}{$\begin{array}{c}\text { No. of oyster bars receiving } \\
\text { monitoring activities }\end{array}$} \\
\hline & & $\begin{array}{l}\text { Substrate } \\
\text { addition }\end{array}$ & $\begin{array}{c}\text { Hatchery } \\
\text { seed } \\
\text { transplants }\end{array}$ & $\begin{array}{l}\text { Wild seed } \\
\text { transplants }\end{array}$ & $\begin{array}{c}\text { Bar } \\
\text { cleaning }\end{array}$ & $\begin{array}{l}\text { Bagless } \\
\text { dredging }\end{array}$ & $\begin{array}{c}\text { Monitoring } \\
\text { with } \\
\text { restoration }\end{array}$ & $\begin{array}{c}\text { Monitoring } \\
\text { without } \\
\text { restoration }\end{array}$ \\
\hline \multirow[t]{7}{*}{ Maryland } & DNR & 174 & 6 & 154 & 0 & 0 & 257 & 158 \\
\hline & $\mathrm{CBF}$ & 65 & 73 & 2 & 0 & 0 & ND & ND \\
\hline & ORP & 6 & 68 & 0 & 38 & 0 & 0 & 0 \\
\hline & PRFC & 15 & 1 & 5 & 0 & 0 & 0 & 0 \\
\hline & ANS/MSU & 1 & 1 & 0 & 0 & 0 & 17 & 8 \\
\hline & Miscellaneous & $8 *, 1 \dagger$ & $1 t$ & 0 & 0 & 0 & $72 \S$ & $15 \S$ \\
\hline & Total & 270 & 150 & 161 & 38 & 0 & 346 & 181 \\
\hline \multirow[t]{5}{*}{ Virginia } & VMRC & 168 & 0 & 40 & 13 & 15 & 149 & 190 \\
\hline & $\mathrm{CBF}$ & 0 & 29 & 3 & 0 & 0 & ND & ND \\
\hline & USACE & 9 & 1 & 0 & 0 & 0 & 9 & 0 \\
\hline & VIMS & 0 & 0 & 0 & 0 & 0 & 48 & 140 \\
\hline & Total & 177 & 30 & 43 & 13 & 15 & 206 & 330 \\
\hline
\end{tabular}

* U.S. Army Corps of Engineers. † South River Federation. †L Living Classrooms Foundation. §University of Maryland. ANS/MSU, Academy of Natural Sciences/Morgan State University Estuarine Research Center; CBF, Chesapeake Bay Foundation; DNR, Maryland Department of Natural Resources; ND, no data collected; ORP, Oyster Recovery Partnership; PRFC, Potomac River Fisheries Commission; USACE, U.S. Army Corps of Engineers; VIMS, Virginia Institute of Marine Science; VMRC, Virginia Marine Resources Commission. 
bars in the restored and nonrestored categories. The Virginia Institute of Marine Science (VIMS) performed monitoring only, sampling nonrestored bars much more often than restored bars.

\section{Assessing Restoration Success}

Of the more than 2,000 restoration activities undertaken, a relatively small number were monitored (Table 7). From the data available, it is clear that there has been limited attention to experiments to assess the efficacy of the various restoration activities. As a result, the kinds and types of data required to determine explicitly the success of restoration were generally not recorded. Estimating success requires that data be collected from a bar both prerestoration and several times postrestoration, and that the bar not be subjected to other activities during the postrestoration data collection period unless these activities are planned and replicated across bars. An additional requirement is that the data be collected in a quantitative manner that allows for estimation of oyster density and condition. Unfortunately, many restored bars had multiple restoration activities with harvest permitted and aperiodic or no monitoring, thereby preventing estimation of the effectiveness of an individual restoration method. We illustrate these issues with the following data.

The number of oyster bars with a single restoration activity and associated monitoring during any 5-y period was low, although the percentage of restored bars subsequently monitored was high (Table 8). In Maryland, 53 of 108 bars receiving substrate and 59 of 92 receiving wild seed were monitored both before and after the restoration activity. In Virginia, 6 of 13 bars receiving wild seed and 7 of 10 receiving hatchery seed were preand postmonitored, but only 20 of 128 bars receiving substrate were adequately monitored. A more detailed examination of the timing of the pre- and postmonitoring of the bars with a single restoration activity in a 5-y period indicates that the number of replicates potentially available for an adequate statistical analysis is modest (Table 9). The number of oyster bars with 2 restoration activities and associated monitoring during any 5-y period was also low, but, again, the percentage of restored bars subsequently monitored was high (Table 10). The combinations of adding substrate plus wild or hatchery seed represent

TABLE 7.

Combinations of restoration activities on monitored and unmonitored oyster bars by state from 1990 to 2007 .

\begin{tabular}{|c|c|c|c|c|}
\hline \multirow[b]{2}{*}{ State } & \multirow{2}{*}{$\begin{array}{c}\text { Restoration } \\
\text { activity }\end{array}$} & \multicolumn{2}{|c|}{$\begin{array}{l}\text { Bars with one or more } \\
\text { restoration activity }\end{array}$} & \multirow{2}{*}{$\begin{array}{c}\begin{array}{c}\text { Bars with no } \\
\text { restoration } \\
\text { activity }\end{array} \\
\text { Monitored }\end{array}$} \\
\hline & & Monitored & Unmonitored & \\
\hline \multirow[t]{5}{*}{ Maryland } & None & - & - & 170 \\
\hline & 1 & 177 & 50 & - \\
\hline & 2 different & 74 & 44 & - \\
\hline & 3 different & 24 & 1 & - \\
\hline & 4 different & 8 & - & - \\
\hline \multirow[t]{4}{*}{ Virginia } & None & - & - & 273 \\
\hline & 1 & 118 & 43 & - \\
\hline & 2 different & 42 & 9 & - \\
\hline & 3 different & 4 & - & - \\
\hline
\end{tabular}

a substantial number of restoration activities in both states. Monitoring appears to have been conducted at least once after restoration in $60-80 \%$ of the bars planted.

Although the information in Tables 8, 9, and 10 suggests that some bars in Maryland and Virginia should have adequate data for an analysis of the effect of a restoration activity on the oyster population on that bar, many of these bars were open to harvesting during the same period. Even if they were closed, data required for an assessment of restoration success were usually unavailable. For example, an estimate of abundance requires that the area sampled and the number of oysters per sampled area be recorded. Unfortunately, this type of information was often not collected. Much of the monitoring data cannot be used to estimate densities because they were collected with qualitative dredge samples (although these data may be useful for evaluating other aspects of oyster restoration "success," such as estimating growth rates, age or size at disease infection, years to harvest size, and so forth) Last, some bars received restoration activities more than $5 \mathrm{y}$ apart. For example, if a bar received shell one year and was monitored in subsequent years, then received shell more than $5 \mathrm{y}$ later and was monitored, this activity would count as two bars in our summary table. However, the bars are not true replicates because there could be some residual effect from the earlier activity, making the results of the individual restoration activities uninterpretable. In sum, these caveats reduce the number of cases of restoration activities followed by multiple years of monitoring to a level that is not adequate for a rigorous analysis.

\section{DISCUSSION}

\section{Key Observations and Cautionary Comments}

An important objective of our evaluation effort was to assess the successes and failures of specific restoration activities toward meeting their restoration goals. Important limitations in meeting that objective imposed by the data are summarized here.

\section{Inadequate Data Collection and Replication}

Analyzing the success of an individual restoration project at a particular bar requires focused data collection using sampling techniques that are sufficiently quantitative to compare outcomes with goals for that bar, and for comparison with nonrestored reference bars. It also requires sufficiently long-term monitoring pre- and postrestoration activity to capture the effect of the restoration effort. More general analysis needed to improve the effectiveness of restoration and to meet larger scale goals, however, also requires that both the design of the array of restoration projects and the associated data collection be coordinated and planned with sufficient attention to replication and siting to draw meaningful conclusions. For example, replicating alternative techniques (e.g., bar sizes, substrates, seed densities) and using reference bars in a single habitat (salinity zone, tributary vs. main stem Bay) can guide future restoration efforts in that habitat type by providing information on the relative effectiveness of the tested techniques. Alternatively, replication across habitats can provide information on how the effectiveness of tested techniques varies with environmental conditions.

Despite the large number of restoration activities in the database, the lack of replication of specific combinations of 
TABLE 8.

Number of oyster bars in each state with only 1 restoration activity and associated monitoring over any 5-y period, 1990 to 2007.

\begin{tabular}{|c|c|c|c|c|c|c|c|}
\hline \multirow[b]{2}{*}{ State } & \multirow[b]{2}{*}{ Restoration activity } & \multicolumn{5}{|c|}{ No. of oyster bars } & \multirow[b]{2}{*}{$\begin{array}{r}\text { Total no } \\
\text { of bars }\end{array}$} \\
\hline & & $\begin{array}{l}\text { Restored } \\
\text { only }\end{array}$ & $\begin{array}{c}\text { Only monitored } \\
\text { before restoration }\end{array}$ & $\begin{array}{l}\text { Only monitored } \\
\text { after restoration }\end{array}$ & $\begin{array}{c}\text { Monitored } \\
\text { before and } \\
\text { after restoration }\end{array}$ & $\begin{array}{c}\text { Total } \\
\text { monitoring }\end{array}$ & \\
\hline \multirow[t]{5}{*}{ Maryland } & Substrate addition & 27 & 3 & 25 & 53 & 81 & 108 \\
\hline & Wild seed transplanting & 9 & 0 & 24 & 59 & 83 & 92 \\
\hline & Hatchery seed transplanting & 11 & 2 & 3 & 6 & 11 & 22 \\
\hline & Bar cleaning & 3 & 1 & 0 & 1 & 2 & 5 \\
\hline & Subtotal & 50 & 6 & 52 & 119 & 177 & 227 \\
\hline \multirow[t]{7}{*}{ Virginia } & Substrate addition & 38 & 12 & 58 & 20 & 90 & 128 \\
\hline & Wild seed transplanting & 3 & 2 & 2 & 6 & 10 & 13 \\
\hline & Hatchery seed transplanting & 1 & 0 & 2 & 7 & 9 & 10 \\
\hline & Bagless dredging & 0 & 4 & 0 & 5 & 9 & 9 \\
\hline & Bar cleaning & 1 & 0 & 0 & 0 & 0 & 1 \\
\hline & Subtotal & 43 & 18 & 62 & 38 & 118 & 161 \\
\hline & Total & 93 & 24 & 114 & 157 & 295 & 388 \\
\hline
\end{tabular}

restoration activities in or among habitats severely hampered our ability to evaluate the effectiveness of restoration to date. An analysis of activities at 57 bars in Maryland that were both closed to harvest for at least $1 \mathrm{y}$ and for which data on live oysters were collected sometime during the 18-y study period reveals that replication of specific techniques was rare. Eleven of the bars received no restoration activity and so could serve as replicates of that action. However, the remaining 46 bars received 34 different combinations of restoration activities. One restoration activity — shell addition — had 6 replicates (unfortunately, the collected data were not quantitative); three other combinations of restoration activities had three possible replicates each, 1 had 2, and the remaining 29 combinations were unreplicated.

If we relax the criteria for inclusion of bars in analyses and pool bars receiving 1 or 2 repetitions of the same activities, 4 restoration types had at least 4 replicates: (1) shell addition and hatchery seed addition, (2) shell addition only, (3) hatchery seed addition only, and (4) bars receiving no restoration activities.
Although these "treatments" would seem to form a basis for important analyses (e.g., Does addition of hatchery seed provide any benefit beyond addition of shell only?), variation among potential replicates renders some data unsuitable for such comparisons. For example, of 8 bars with 1 or 2 shell additions and hatchery-seed additions, (1) the number of years between shell additions and hatchery seed additions ranged from $0-7 \mathrm{y}$, (2) 2 bars were not actually closed to fishing the year after shell addition or in the subsequent year, and (3) only 3 bars were both monitored and closed for at least $2 \mathrm{y}$ after seed addition. Furthermore, bars receiving similar restoration activities often varied in habitat, size, and specifics of the restoration techniques used.

A similar analysis of data from Virginia is currently not possible. The opening dates and durations of opening of the Virginia public oyster grounds for harvesting are set annually by VMRC at their September meeting. Occasionally, the dates and durations of opening have been modified by emergency action at subsequent meetings. These actions are recorded in the

TABLE 9.

Number of oyster bars in each state with monitoring during the year of the activity (year 0 ) and for as long as $4 \mathrm{y}$ thereafter, 1990 to 2007.

\begin{tabular}{|c|c|c|c|c|c|c|c|}
\hline \multirow[b]{2}{*}{ State } & \multirow[b]{2}{*}{ Restoration activity } & \multicolumn{5}{|c|}{ No. of oyster bars } & \multirow[b]{2}{*}{$\begin{array}{r}\text { Total no. } \\
\text { of bars }\end{array}$} \\
\hline & & $\begin{array}{l}\text { Monitored } \\
\text { year } 0\end{array}$ & $\begin{array}{c}\text { Monitored } \\
\text { years } 0 \text { and } 1\end{array}$ & $\begin{array}{c}\text { Monitored } \\
\text { years } 0,1 \text {, and } 2\end{array}$ & $\begin{array}{c}\text { Monitored } \\
\text { years 0-3 }\end{array}$ & $\begin{array}{c}\text { Monitored } \\
\text { years 0-4 }\end{array}$ & \\
\hline \multirow[t]{5}{*}{ Maryland } & Substrate addition & 3 & 10 & 6 & 5 & 43 & 67 \\
\hline & Wild seed transplanting & 6 & 4 & 7 & 5 & 55 & 79 \\
\hline & Hatchery seed transplanting & 1 & 2 & 2 & 0 & 4 & 9 \\
\hline & Bar cleaning & 1 & 0 & 0 & 0 & 0 & 1 \\
\hline & Subtotal & 11 & 16 & 15 & 10 & 102 & 154 \\
\hline \multirow[t]{6}{*}{ Virginia } & Substrate addition & 8 & 9 & 7 & 10 & 11 & 45 \\
\hline & Wild seed transplanting & 1 & 0 & 0 & 1 & 5 & 7 \\
\hline & Hatchery seed transplanting & 3 & 2 & 2 & 0 & 2 & 9 \\
\hline & Bagless dredging & 0 & 0 & 0 & 0 & 3 & 3 \\
\hline & Subtotal & 12 & 11 & 9 & 11 & 21 & 64 \\
\hline & Total & 23 & 27 & 24 & 21 & 123 & 218 \\
\hline
\end{tabular}


TABLE 10.

Number of oyster bars in each state with 2 restoration activities (involving 3 of the most common restoration activities) and associated monitoring over any 5-y period, 1990 to 2007.

\begin{tabular}{|c|c|c|c|c|c|c|c|}
\hline \multirow[b]{2}{*}{ State } & \multirow[b]{2}{*}{ Combined restoration activities } & \multicolumn{5}{|c|}{ No. of oyster bars } & \multirow[b]{2}{*}{$\begin{array}{r}\text { Total no } \\
\text { of bars }\end{array}$} \\
\hline & & $\begin{array}{c}\text { Restored } \\
\text { only }\end{array}$ & $\begin{array}{c}\text { Only } \\
\text { monitored } \\
\text { before } \\
\text { restoration }\end{array}$ & $\begin{array}{c}\text { Only } \\
\text { monitored } \\
\text { after } \\
\text { restoration }\end{array}$ & $\begin{array}{c}\text { Monitored } \\
\text { before and } \\
\text { after restoration }\end{array}$ & $\begin{array}{c}\text { Total } \\
\text { monitoring }\end{array}$ & \\
\hline \multirow[t]{2}{*}{ Maryland } & Substrate addition and hatchery seed planting & 39 & 5 & 58 & 24 & 87 & 126 \\
\hline & Substrate addition and wild seed planting & 38 & 4 & 111 & 42 & 157 & 195 \\
\hline \multirow[t]{2}{*}{ Virginia } & Substrate addition and hatchery seed planting & 40 & 12 & 29 & 51 & 92 & 132 \\
\hline & Substrate addition and wild seed planting & 42 & 14 & 30 & 52 & 96 & 138 \\
\hline
\end{tabular}

meeting minutes. Typically, whole estuaries or sections of estuaries are defined as open or closed areas, with delineating landmarks such as buoys being identified for enforcement purposes. Individual bars are less frequently identified in regulations guiding opening and closing of harvests. Assembly of such historical data for this project's period of interest requires examination of the monthly minutes and subsequent translation of the boundary data to bar designations in the GIS databases.

\section{Confounding Effects of Harvesting}

Most restoration activities in Maryland were associated with "open" oyster bars, indicating that restoration efforts were targeted to support the fishery. For example, in Maryland, 388 bars were open to the fishery between 1990 and 2007, and were also monitored at some point during the study period. Of those bars, 235 had at least one restoration activity performed. Additional fishery-related restoration activities in Maryland were associated with oyster bars that were closed for one to several years before being reopened. For example, there were 46 bars with at least one restoration activity that were closed at some point during the study period. In Virginia, data for open and closed areas were not available in an electronic or other format that was compatible with the database. Hence, the intent of restoration efforts for most bars in Virginia cannot be ascertained at this time.

\section{Limited Quantitative Sampling Effort}

In Maryland, most of the data on oysters came from semiquantitative sampling (timed dredge samples, with no tow distance recorded). For all Maryland samples, regardless of organization, there were 4,439 dredges that had no tow length recorded and 190 monitoring activities that were collected by hand or by a diver with no quadrat sampler involved or with unknown gear. The DNR alone performed 4,018 dredge tows with no distances recorded. Quantitative, spatially explicit sampling by the DNR (timed dredges, patent tong use, or quadrat sampling) comprised just 1,013 activities in Maryland, including 806 dredge samples with distances recorded and 181 patent tong samples.

The semiquantitative data may serve the purposes for which they were intended (e.g., evaluating recruitment success or informing fisheries management decisions), but unfortunately cannot be used to assess the success or failure of many restoration activities with respect to population dynamics and quantitative abundance estimates. In addition, harvest data are not available for specific bars, so we cannot determine whether restoration efforts resulted in improved harvests. However, it is possible that the associated disease data will be useful for addressing potential changes in disease status on restored bars.

In Virginia, VMRC and VIMS collected 2,726 samples by dredge, by hand, by diver with no quadrat in hand, or by unknown means. An additional 772 samples were taken by patent tong or by a diver with a quadrat sampler. Overall, a greater proportion of monitoring data was collected by spatially explicit sampling in Virginia. VMRC alone collected 997 samples by divers using quadrats or patent tongs versus 149 by untimed dredge samples. However, several issues need to be resolved to make good use of the quantitative Virginia sampling. Different sampling protocols have yielded different density estimates, and, as noted earlier, restoration goals and information on whether bars were closed to fishing during and subsequent to restoration efforts are missing. In addition, data on numbers of replicate samples taken for much of the Virginia monitoring data have not been provided. The absence of this information precludes useful analyses.

\section{What Conclusions Have We Drawn?}

We conclude that the limitations cited earlier hinder using the database to evaluate the success or failure of specific restoration activities on specific oyster bars or the efficacy of particular restoration techniques in general. Further data collection efforts, such as the harvest pattern for bars in Virginia, might reveal additional information that would make the data in our database more useful.

Recent collaborative restoration efforts in Virginia (U.S. Army Corps of Engineers, VMRC, VIMS) and in Maryland (Oyster Recovery Partnership) have been more explicit in their goals and more thoroughly monitored. Designation of specific restoration bars as sanctuaries (e.g., Palace Bar Reef in the Piankatank River, VA, or Shoal Creek and States Bank in the upper Choptank River, MD) imply ecological goals. However, such designations do not distinguish between particular ecosystem services that are being targeted (e.g., a spawner sanctuary for repopulating the region vs. provision of habitat on the sanctuary bar itself). Monitoring activities associated with these bars generally included quantitative estimates of recruitment and population abundance, oyster growth and survival, and disease prevalence and intensity. The data derived from these more quantitative activities may allow an interested party to determine success or failure of individual projects. However, 
activities not recorded in the data set (e.g., poaching on sanctuary bars) could hinder any effort to interpret the results of statistical analyses of the available data. Furthermore, the limited number of replicates in relation to sampling techniques, salinity zones, and habitats will hinder the ability to draw general lessons from multiproject comparisons.

A widespread restoration activity throughout the period was the addition of substrate, which can result in short-term enhancement of oyster recruitment (e.g., Brumbaugh \& Coen 2009). Our database may permit an evaluation of this issue on a broader scale. However, the lack of data on other possible effects on recruitment, such as sediment and fouling organisms on shells, limits the ability to ascribe causes to any patterns uncovered.

To supplement broodstocks and to increase spawning success, oysters have been added to sanctuary bars by governmental and nongovernmental organizations with increasing frequency during the study period (150 bars had hatchery seed transplanted and 100 bars had wild seed transplanted at some point during the study period). Some recent reports have supported the utility of supplementing broodstock (e.g., Southworth \& Mann 1998, Brumbaugh \& Coen 2009). Unfortunately, most of the bars in our study had several restoration activities at different times with different monitoring activities and different closure dates. As a result, the combined data set will not provide the foundation for satisfactory analyses.

Although the inferred goals of some of the activities in the database included the restoration of ecological functions provided by oyster bars, few studies collected data directly related to those functions other than those (e.g., filtration rates) that can be directly calculated from size and abundance data. Recent studies on restored oyster bars in low-salinity areas in Maryland (the Chester, Choptank, Severn, and Patuxent rivers) and in mesohaline areas in Virginia (the lower Rappahannock River) have related some additional aspects of ecological functions to oyster abundance data (Luckenbach et al. 2005; Paynter et al. 2010). The ability to use the database to extend the inferences from these studies to other restoration bars is uncertain at this point, but we expect that comparisons between bars might enhance the ability to infer ecological success where they have not been specifically measured. Those inferences, of course, depend on the similarity of data collection methods and timing of the sampling between bars.

One final caution involves the natural high variability in oyster population dynamics, including the extremely large yearto-year variability in spat settlement in Chesapeake Bay (e.g.,
Shaw 1969, Krantz \& Meritt 1977, Kennedy 1980, Newell et al. 2000). The presence of such variability requires longer term studies than have been performed to date when assessing whether a restoration activity has modified local population dynamics in a positive way or whether sustained restoration efforts would be required to increase the oyster population in the Bay.

Our analysis strongly suggests that restoration and monitoring efforts need to be organized and coordinated in a much more stringent manner to facilitate the collection of data essential for assessing the efficacy of these efforts. In our study, 12 different agencies and organizations provided data in various formats. The combined efforts are remarkable in many respects and the analyses we conducted make clear the many ways that these entities have worked together to address the challenge of oyster restoration. However, given the wide range of habitats and the types and combinations of restoration activities implemented, we could draw few conclusions about the efficacy of most restoration efforts. We do conclude, however, that monitoring and management protocols of most restoration activities have been inadequate for any evaluation of the success of any activity on a particular bar. To allow future rehabilitation efforts to be successful, a robust stock assessment program (monitoring) is required to detect local and systemwide changes that may be the result of restoration activities. This assessment program needs to be capable of tracking spatially explicit (i.e., bar-specific) changes in oyster abundance, mean oyster size, recruitment, disease levels, and mortality over time.

\section{RECOMMENDATIONS}

Definitive steps can be taken to improve and enhance restoration and stock assessment efforts (Table 11). To begin, there must be clearly articulated goals for these efforts, whether to support the oyster fishery, for long-term restoration of ecological services, or both. To accomplish these goals will require scientifically rigorous designs for restoring a region, accompanied by preand postmonitoring and specific assessment plans. For example, the restoration project described in Schulte et al. (2009) used before-and-after bottom substrate and oyster population assessments to evaluate an experimental test of potential benefits of vertical relief for fostering oyster growth and population increases. Different end points will likely require different designs for given activities, and possibly different methods of sample collection. Data collection should include repeated

\section{TABLE 11.}

Recommendations for future oyster restoration and monitoring activities.

1. Clearly articulate goals of restoration efforts.

2. Use scientifically valid designs for restoration and monitoring.

3. Collect repeated measures of oyster sizes, abundances, and disease status as well as other goal-specific data.

4. Use georeferencing technology to ensure that all measurements are spatially explicit so that sites can be identified accurately and easily in the future.

5. Organizations doing restoration and monitoring must collaborate, including identifying bars each will restore before manipulations, with all entities agreeing on common variables to be monitored and committing to rigorous quality control for all monitoring efforts.

6. Post data to a central collaborative database governed by clear guidelines for how and when data are to be provided and by clear agreements regarding data availability, sharing, and use.

7. Restored bars must remain unharvested so that monitoring of growth and the progression of disease can continue for a sufficient duration to assess completely the efficacy of the restoration activity. 
measures of oyster size, abundance, and disease status as well as other goal-specific data. Such efforts will require some form of random sampling and measures of effort. It is important that sites can be identified accurately and easily in the future, so georeferencing technology is essential. Sustained funding will be required to support these long-term efforts.

Effective restoration will be greatly enhanced by collaboration among organizations for single site-specific restoration, and more fully integrated data collection and monitoring of critical variables that are common to all efforts and that are subject to rigorous quality control. Collected data should be posted to a central collaborative database that should build on the work of this project and should explicitly identify the potential limitations of contributed data. The database should also be governed by clear guidelines for how and when data are to be provided, and should be based on clear agreements regarding data availability, sharing, and use. Although publication rights could be legitimately restricted to protect the efforts of those involved in monitoring, the database should be accessible to all stakeholders interested in the outcome of public investments in oyster restoration. Last, harvesting must be banned from restored bars during monitoring periods so that monitoring of growth and the progression of disease is main- tained for sufficient duration to assess fully the efficacy of the restoration activity.

Maryland and Virginia are not alone in experiencing the decline of populations of oysters and the loss of ecological services provided by this supreme ecological engineer. Shellfish bars worldwide are diminishing (Beck et al. 2011). However, there remains great interest and substantial investment of public funds in restoring oyster bars in Chesapeake Bay. Our findings should enable future efforts to be more successful.

\section{ACKNOWLEDGMENTS}

We gratefully acknowledge Verna Harrison (Keith Campbell Foundation) and Peyton Robertson (NOAA Chesapeake Bay Office) for support and encouragement. For contributed data, we thank representatives of the agencies listed in Table 1, as well as George Abbe, Eric Campbell, A. C. Carpenter, and James Wesson. Sandy Rodgers provided the figures and Jack Greer carefully edited the ORET manuscript on which this article is based. Funding was provided by The Keith Campbell Foundation for the Environment, the NOAA Chesapeake Bay Office, the U.S. Fish and Wildlife Service, and the Maryland Sea Grant College Program. UMCES contribution no. 4542.

\section{LITERATURE CITED}

Beck, M. W., R. D. Brumbaugh, L. Airoldi, A. Carranza, L. D. Coen, C. Crawford, O. Defeo, G. J. Edgar, B. Hancock, M. C. Kay, H. S. Lenihan, M. W. Luckenbach, C. L. Toropova, G. Zhang \& X. Guo. 2011. Oyster reefs at risk and recommendations for conservation, restoration, and management. Bioscience 61:107-116.

Breitburg, D., L. D. Coen, M. W. Luckenbach, R. Mann, M. Posey \& J. A. Wesson. 2000. Oyster reef restoration: convergence of harvest and conservation strategies. J. Shellfish Res. 19:371-377.

Brooks, W. K. 1891 The oyster: a popular summary of a scientific study. Baltimore, MD: The Johns Hopkins Press. 230 pp. Reissued by Johns Hopkins University Press in 1996 with a foreword by K. T. Paynter, Jr.

Brumbaugh, R. D. \& L. D. Coen. 2009. Contemporary approaches for small-scale oyster reef restoration to address substrate versus recruitment limitation: a review and comments relevant for the Olympia oyster, Ostrea lurida Carpenter 1864. J. Shellfish Res. 28:147-161.

Coen, L. D. \& M. W. Luckenbach. 2000. Developing success criteria and goals for evaluating oyster reef restoration: ecological function or resource exploitation? Ecol. Eng. 15:323-343.

Coen, L. D., M. W. Luckenbach \& D. L. Breitburg. 1999. The role of oyster reefs as essential fish habitat: a review of current knowledge and some new perspectives. In: L. R. Benaka, editor. Fish habitat: essential fish habitat and rehabilitation. Bethesda, MD: American Fisheries Society Symposium 22. pp. 438-454.

Grabowski, J. H. \& C. H. Peterson. 2007. Restoring oyster reefs to recover ecosystem services. In: K. Cuddington, J. E. Byers, W. G. Wilson \& A. Hastings, editors. Ecosystem engineers: plants to protists. New York, NY: Elsevier Press. pp. 281-298.

Grave, C. 1912. History of oyster production in Maryland, 1810-1912. Report of the Proceedings of the Third Annual Convention of the National Association of Shellfish Commissioners. pp. 64-73.

Hargis, W. J., Jr. \& D. S. Haven. 1988. Rehabilitation of the troubled oyster industry of the lower Chesapeake Bay. J. Shellfish Res. 7: 271-279.

Hargis, W. J., Jr. \& D. S. Haven. 1999. Chesapeake oyster reefs, their importance, destruction and guidelines for restoring them. In: M. W. Luckenbach, R. Mann \& J. A. Wesson, editors. Oyster reef habitat restoration: a synopsis and synthesis of approaches. Gloucester Point, VA: VIMS Press. pp. 329-358.

Kennedy, V. S. 1980. Comparison of recent and past patterns of oyster settlement and seasonal fouling in Broad Creek and Tred Avon River, Maryland. Proc. Natl. Shellfish. Assoc. 70:36-46.

Kennedy, V. S. 1989. The Chesapeake Bay oyster fishery: traditional management practices. In: J. F. Caddy, editor. Marine invertebrate fisheries: their assessment and management. New York, NY: Wiley. pp. 455-477.

Kennedy, V. S. 1996. The ecological role of the Eastern oyster, Crassostrea virginica, with remarks on disease. J. Shellfish Res. 15: 177-183.

Kennedy, V. S. \& L. L. Breisch. 1983. Sixteen decades of political management of the oyster fishery in Maryland's Chesapeake Bay. J. Environ. Manage. 16:153-171.

Krantz, G. E. \& D. W. Meritt. 1977. An analysis of trends in oyster spat set in the Maryland portion of Chesapeake Bay. Proc. Natl. Shellfish. Assoc. 67:53-59.

Luckenbach, M. W., L. D. Coen, P. G. Ross, Jr. \& J. A. Stephen. 2005. Oyster reef habitat restoration: relationship between oyster abundance and community development based on two studies in Virginia and South Carolina. J. Coast. Res. (Special issue) 40:64-78.

Newell, R. I. E. 1988. Ecological changes in Chesapeake Bay: are they the result of overharvesting the American oyster, Crassostrea virginica? In: M. P. Lynch \& E. C. Krome, editors. Understanding the estuary: advances in Chesapeake Bay research. Publication no. 129 CBP/TRS 24/88. Gloucester Point, VA: Chesapeake Research Consortium. pp. 536-546.

Newell, R. I. E., G. S. Alspach, V. S. Kennedy \& D. Jacobs. 2000. Mortality of newly metamorphosed Eastern oysters (Crassostrea virginica Gmelin) in mesohaline Chesapeake Bay. Mar. Biol. 136 665-676.

ORET (Oyster Restoration Evaluation Team). 2009. Metadata analysis of restoration and monitoring activity database. In: J. G. Kramer \& K. G. Sellner, editors. Native oyster (Crassostrea virginica) restoration in Maryland and Virginia: an evaluation of lessons learned 1990-2007. Maryland Sea Grant publication no. UM-SG-TS-200902; CRC publication no. 09-168. College Park, MD. pp. 1-43. 
Paynter, K. P., V. Politano, H. A. Lane, S. M. Allen \& D. Meritt. 2010. Growth rates and Perkinsus marinus prevalence in restored oyster populations in Maryland. J. Shellfish Res. 29:309-317.

Rodney, W. S. \& K. T. Paynter. 2006. Comparisons of macrofaunal assemblages on restored and non-restored oyster reefs in mesohaline regions of Chesapeake Bay in Maryland. J. Exp. Mar. Biol. Ecol. 335:39-51.

Rothschild, B. J., J. S. Ault, P. Goulletquer \& M. Héral. 1994. Decline of the Chesapeake Bay oyster population: a century of habitat destruction and overfishing. Mar. Ecol. Prog. Ser. 111:29-39.

Schulte, D. M., R. P. Burke \& R. N. Lipcius. 2009. Unprecedented restoration of a native oyster metapopulation. Science 325:1124-1128.

Shaw, W. N. 1969. Oyster setting in two adjacent tributaries of Chesapeake Bay. Trans. Am. Fish. Soc. 98:309-314.

Southworth, M. \& R. Mann. 1998. Oyster reef broodstock enhancement in the Great Wicomico River, Virginia. J. Shellfish Res. 17:1101-1114.
Stevenson, C. H. 1894. The oyster industry of Maryland. Bull. U.S. Fish Commission for 1892. 12:205-297.

USEPA (U.S. Environmental Protection Agency). 2008. 2008 92Segment scheme for the Chesapeake Bay water quality criteria. In: Ambient water quality criteria for dissolved oxygen, water clarity and chlorophyll $a$ for the Chesapeake Bay and its tidal tributaries. 2008 Technical support for criteria assessment protocols addendum. EPA903-R- 08-001; CBP/TRS 290-08. Annapolis, MD. Chesapeake Bay Program Office. pp. 5-12. <http://www. chesapeakebay.net/content/publications/cbp_47637.pdf $>$ Accessed August 7, 2011.

Wesson, J., R. Mann \& M. Luckenbach. 1999. Oyster restoration in Virginia. In: M. W. Luckenbach, R. Mann \& J. A. Wesson, editors. Oyster reef habitat restoration: a synopsis and synthesis of approaches. Gloucester Point, VA: VIMS Press. pp. 117-129. 